\title{
The Effect of Salinity on Membrane Fouling Characteristics in an Intermittently Aerated Membrane Bioreactor
}

\author{
Kang Xie, ${ }^{1}$ Siqing Xia, ${ }^{2}$ Jing Song, ${ }^{3}$ Jixiang $\mathrm{Li},{ }^{4}$ Liping Qiu, \\ Jiabin Wang, ${ }^{1}$ and Shoubin Zhang ${ }^{1}$ \\ ${ }^{1}$ School of Civil Engineering and Architecture, University of Jinan, Jinan, Shandong 250022, China \\ ${ }^{2}$ State Key Laboratory of Pollution Control and Resource Reuse, College of Environmental Science and Engineering, \\ Tongji University, Shanghai 200092, China \\ ${ }^{3}$ Shandong Province Environmental Protection Technology Service Center, Jinan, Shandong 250102, China \\ ${ }^{4}$ Shanghai Advanced Research Institute, Chinese Academy of Sciences, Shanghai 201203, China
}

Correspondence should be addressed to Kang Xie; sdxkang@gmail.com and Siqing Xia; otw1208@gmail.com

Received 24 April 2014; Revised 13 July 2014; Accepted 16 July 2014; Published 5 August 2014

Academic Editor: Chaomeng Dai

Copyright (C) 2014 Kang Xie et al. This is an open access article distributed under the Creative Commons Attribution License, which permits unrestricted use, distribution, and reproduction in any medium, provided the original work is properly cited.

The effect of salinity on the membrane fouling characteristics was investigated in the intermittently aerated membrane bioreactor (IAMBR). Five different salinity loadings were set from 0 to $35 \mathrm{~g} \cdot \mathrm{L}^{-1}$ (referring to $\mathrm{NaCl}$ ), respectively. The removal of total organic carbon (TOC) and ammonia-nitrogen $\left(\mathrm{NH}_{4}{ }^{+} \mathrm{-N}\right)$ was gradually decreased with increasing salinity. The variation of membrane filtration resistance, particle size distribution (PSD), extracellular polymeric substances (EPS), soluble microbial products (SMP), and relative hydrophobicity $(\mathrm{RH})$ analysis revealed that salinity has a significant effect on sludge characteristics in IAMBR. The results also indicated that the membrane fouling is often caused by the integration of sludge characteristics in saline wastewater.

\section{Introduction}

Recent years, with the rapid development of economy, pollutions of water environment, and shortages of water resource are becoming the most important problems for public health [1]. In addition, the increasing environmental protection requirements need new technologies to make a better effluent quality. Membrane bioreactor (MBR) where activated sludge process is combined with membrane filtration has been widely used for wastewater treatment and reuse. MBR is able to provide small footprint, perfect effluent, higher biodegradation efficiency, and less excess sludge, regarding as an innovative and promising technology [2]. However, membrane fouling, which reduces membrane permeability and increases operational cost, is still the major obstacles for the wider application of MBR in biological wastewater treatment. It is extensively studied by focusing on fouling factors, such as sludge characteristics, operational conditions, feedwater characteristics, aeration, hydraulic conditions, and membrane materials [3]. In general, complex membrane foulants and sludge characteristics are assumed to be the main cause of membrane fouling. Sludge characteristics are direct affected by operating parameters, dissolved oxygen, organic loading, salinity,and so on. The understanding of inorganic fouling in saline wastewater is still not clear. Once the inorganic scaling forms on the membrane surface, it is difficult to be eliminated using chemical cleaning [4]. Therefore, more attention should be paid to membrane fouling in saline wastewater.

Industrial wastewater, wastewater recycling, and seawater utilization often lead to high salinity in discharged wastewater. In general, effluent of many industries such as food processing, leather, petroleum, dairy, and fish processing often causes saline wastewater, which increased rapidly over the last decades [5-7]. Furthermore, in areas lacking fresh water, such as Hong Kong, seawater can be used for toilet flushing in order to save freshwater, resulting in higher salinity in wastewater treatment plant (WWTP) [8]. These high salinity wastewaters often contain large amounts of soluble inorganic salts combined with organic compounds. 
For conventional activated sludge system, high salinity has been shown to cause plasmolysis and loss of activity of cells because of the unbalance of osmotic stress [9].

However, the MBR is considered as a promising technology to treat salinity wastewater, owing to higher biomass concentration retained by membrane filtration and longer sludge retention time. Several studies have recently reviewed saline wastewater treatment using MBR. Jang et al. [10] investigated the effect of salinity on the performance and membrane fouling in MBR. The results showed a decreasing of ammonia removal and significant changes of microbial community composition. And then, the membrane fouling increased with elevated salinity. Johir et al. [11] also showed a poor performance at higher salinity $\left(35 \mathrm{~g} \cdot \mathrm{L}^{-1}\right)$.

It is known that a modification in biomass kinetics as well as in sludge characteristics would be attained in MBR treating saline wastewater, which can significantly influence the development of membrane fouling. The SMP, EPS, PSD, and so on were investigated by previous studies [12, 13] trying to examine the relation between sludge characteristics and membrane fouling in saline wastewater. Nevertheless, it has not completely elucidated the variation of sludge characteristics and membrane fouling at different salinities.

Therefore, an IAMBR was used to treat salinity wastewater in this study, and the main aim of this study was to investigate the system performance and variation of sludge characteristics such as PSD, EPS, SMP, and RH at different salinity.

\section{Materials and Methods}

2.1. IAMBR Setup and the Operation. As shown in Figure 1, an intermittently aerated membrane bioreactor (IAMBR) was operated to treat salinity contained municipal wastewater in this study. The effective volume of the bioreactor was $8 \mathrm{~L}$. The IAMBR was equipped with two hollow fiber polyvinylidene fluoride (PVDF) ultrafiltration (UF) membrane modules (Litree Company, Suzhou, China) with a total surface area of $0.12 \mathrm{~m}^{2}$ and nominal pore size of $0.02 \mu \mathrm{m}$. The outer and inner diameters of the fibers were $1.45 \mathrm{~mm}$ and $0.85 \mathrm{~mm}$, respectively. Permeate was extracted by a peristaltic pump at a permeate flux of $5 \mathrm{~L} \cdot \mathrm{m}^{-2} \cdot \mathrm{h}^{-1}$ with mode of $10 \mathrm{~min}$ filtration and $2 \mathrm{~min}$ rest. The transmembrane pressure (TMP) was monitored by a vacuum meter (Weiken YN-60, Shanghai). Intermittent aeration was supplied by air diffuser at the bottom of the membrane module with the air blower switch on/off. The air flow rate was $0.6 \mathrm{~m}^{3} \cdot \mathrm{h}^{-1}$ in order to provide oxygen for biological treatment and to alleviate membrane fouling and cake formation. The IAMBR was operated in cycles of 3 hours: 1 hour anoxic reaction without aeration and filtration (anoxic phase) and 2 hours aerobic reaction membrane filtration (aerobic phase). At the beginning of the anoxic phase, the synthetic wastewater was fed to the reactor for about 10 minutes until water level reaching $8 \mathrm{~L}$. The water level was dropped until $6 \mathrm{~L}$ at the end of each cycle during the filtration period. Therefore, the hydraulic retention time (HRT) was 12 hours in the IAMBR.

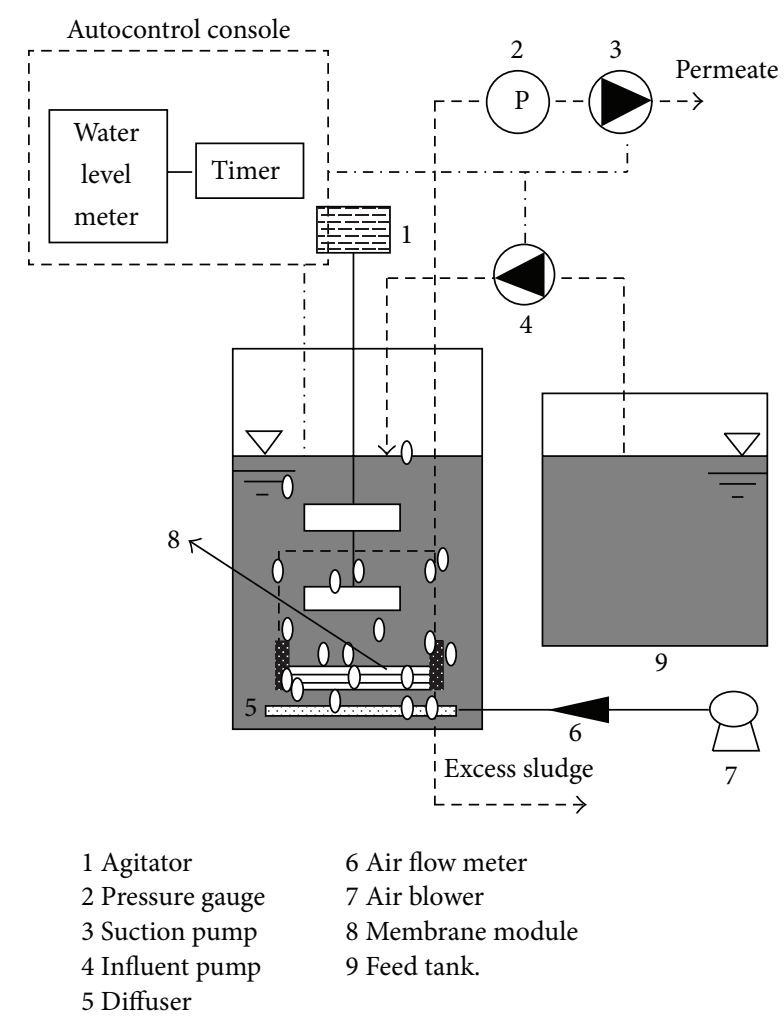

FIGURE 1: Schematic diagram of the bench-scale IAMBR.

During the acclimation period, five parallel IAMBRs (acclimated reactors) were inoculated with activated sludge obtained from QuYang municipal wastewater treatment plant (Shanghai, China). The IAMBRs fed with synthetic wastewater comparable to domestic wastewater adding salinity according to Xie et al. [14]. The main constituent of the synthetic wastewater was shown in Table 1 . The salinity levels were expressed as the concentration of sodium chloride $(\mathrm{NaCl})$. The $\mathrm{NaCl}$ concentrations of five IAMBRs were 0 , $5,10,15,20$, and $35 \mathrm{~g} \cdot \mathrm{L}^{-1}$, respectively. The salinity level in each reactor gradually increased from 0 to $35 \mathrm{~g} \cdot \mathrm{L}^{-1}$ with every $5 \mathrm{~g} \cdot \mathrm{L}^{-1}$. After the sludge was matured, it was taken to other five small reactors (operated reactors), respectively. The concentration of mixed liquor suspended solids (MLSS) in each operated reactor was maintained at $5000 \pm 210 \mathrm{mg} / \mathrm{L}$. The HRT, SRT, aeration intensity, and so on were controlled at the same operating mode. The temperature was maintained at $25 \pm 2^{\circ} \mathrm{C}$.

2.2. Analytical Methods. The influent and effluent were collected daily from the five reactors. The total organic carbon (TOC) was measured instead of chemical oxygen demand (COD), because of the limitations of COD when measuring the organic matter in wastewater samples with chlorides higher than $2000 \mathrm{mg} \cdot \mathrm{L}^{-1}$. TOC was determined by a TOC analyzer with autosampler (TOC V-CPN, Shimadzu, Japan). The $\mathrm{NH}_{4}{ }^{+}-\mathrm{N}$, MLVSS (mixed liquor volatile suspended solid), and MLSS were measured according to Chinese NEPA standard methods [15]. The transmembrane pressure (TMP) 
TABLE 1: The main constituent of the synthetic wastewater.

\begin{tabular}{lccccc}
\hline Main composition & Glucose & Corn starch & Peptone & $\mathrm{NH}_{4} \mathrm{Cl}$ & $\mathrm{KH}_{2} \mathrm{PO}_{4}$ \\
\hline Concentration $\left(\mathrm{mg} \cdot \mathrm{L}^{-1}\right)$ & 250 & 250 & 28 & 30.8 \\
Main composition & $\mathrm{MgSO}_{4} \cdot 7 \mathrm{H}_{2} \mathrm{O}$ & $\mathrm{MnSO}_{4} \cdot 7 \mathrm{H}_{2} \mathrm{O}$ & $\mathrm{FeSO}_{4}$ & $\mathrm{CaCl}_{2}$ & $\mathrm{NaHCO}_{3}$ \\
Concentration $\left(\mathrm{mg} \cdot \mathrm{L}^{-1}\right)$ & 9 & 6 & 0.3 & 8 & 120 \\
\hline
\end{tabular}

TABLE 2: Variations and removal efficiencies of TOC in five IAMBRs of different salinity during steady operations.

\begin{tabular}{|c|c|c|c|}
\hline Salinity $\left(\mathrm{g} \cdot \mathrm{L}^{-1}\right)$ & Influent $\left(\mathrm{mg} \cdot \mathrm{L}^{-1}\right)$ & Effluent $\left(\mathrm{mg} \cdot \mathrm{L}^{-1}\right)$ & Removal efficiency (100\%) \\
\hline 0 & $106.6 \pm 40.3$ & $4.9 \pm 1.9$ & $95.3 \pm 4.7$ \\
\hline 5 & $115.7 \pm 16.9$ & $4.8 \pm 2.1$ & $95.8 \pm 1.6$ \\
\hline 10 & $110.9 \pm 14.1$ & $4.7 \pm 1.3$ & $95.7 \pm 1.3$ \\
\hline 15 & $111.7 \pm 20.9$ & $9.4 \pm 3.0$ & $91.6 \pm 1.6$ \\
\hline 20 & $112.8 \pm 22.0$ & $10.3 \pm 3.6$ & $90.9 \pm 2.0$ \\
\hline 35 & $110.5 \pm 19.4$ & $18.3 \pm 7.1$ & $83.4 \pm 3.6$ \\
\hline
\end{tabular}

was recorded with using a vacuum meter (YN-60, Shanghai Weiken). Dehydrogenase activity (DHA) was estimated using redox sensitive 2,3,5-triphenyltetrazolium chloride (TTC) followed Reddy's description [16]. The DHA was estimated by mg TF per g MLSS and per hour.

2.3. Evaluation of Filtration Resistance. Membrane resistance was characterized by the resistance-in-series model according to Meng et al. [17] as follows:

$$
R_{t}=R_{m}+R_{p}+R_{c}=\frac{\Delta \mathrm{TMP}}{\mu J},
$$

where $R_{t}$ is the total membrane resistance $\left(\mathrm{m}^{-1}\right), R_{m}$ is the intrinsic resistance of the new membrane $\left(\mathrm{m}^{-1}\right), R_{p}$ is the pore blocking resistance $\left(\mathrm{m}^{-1}\right), R_{c}$ is the cake resistance $\left(\mathrm{m}^{-1}\right), \Delta \mathrm{TMP}$ is the transmembrane pressure difference (Pa), $\mu$ is permeate viscosity $(\mathrm{Pa} \cdot \mathrm{s})$, and $J$ is permeate flux $\left(\mathrm{m}^{3} \cdot \mathrm{m}^{-2} \cdot \mathrm{s}^{-1}\right)$. Total resistances were calculated from the flux, the transmembrane pressure difference, and the viscosity.

2.4. PSD Analysis. The mixed liquor samples were collected from the 5 different salinity operated reactors. The PSD was analyzed using a laser granularity distribution analyzer (Eye Tech Particle Size and Shape Analyzer, USA) with a detection range of $0.1-3600 \mu \mathrm{m}$.

2.5. EPS and SMP Analyses. EPS and SMP were extracted from the mixed liquors in each operated reactor according to the previous study [2]. Both the EPS and SMP concentrations were expressed by the carbohydrates and proteins. The carbohydrates concentrations were determined by the anthrone method with glucose as a standard, and the proteins concentrations were measured using the bicinchoninic acid assay (BCA) with bovine serum albumin as a standard. Both the EPS and SMP analyses were performed in triplicate, and the average value was calculated.

2.6. $R H$. The $\mathrm{RH}$ was measured as described previously [18]. The mixed liquor samples from 5 operated reactors were homogenized by sonication and then were separated by hexadecane. The RH was quantified as the ratio of MLSS concentration in the aqueous phase after emulsification $\left(\mathrm{MLSS}_{e}\right)$ to the concentration of MLSS in the aqueous phase before emulsification $\left(\mathrm{MLSS}_{i}\right)$ :

$$
\mathrm{RH}=\left[1-\left(\frac{\mathrm{MLSS}_{e}}{\mathrm{MLSS}_{i}}\right)\right] .
$$

Each sample was analyzed at least three times, and the average value was calculated. The sludge samples were washed with distilled water in order to avoid the salt interference.

\section{Results and Discussion}

3.1. The Performance of IAMBR at Different Salinity. After the activated sludge of 5 acclimated reactors was matured, the steady stage was reached. The influent and effluent were collected daily from each acclimated reactor for a long time under the steady stage, and the TOC and $\mathrm{NH}_{4}{ }^{+}-\mathrm{N}$ were measured (Tables 2 and 3). As is shown in Tables 2 and 3 , the TOC removal showed a similar tendency as that of $\mathrm{NH}_{4}{ }^{+}-\mathrm{N}$ at different salinity of acclimated reactors. In view of the effluent quality, removal of TOC and $\mathrm{NH}_{4}{ }^{+}-\mathrm{N}$ performed stably during the influent salinity increased from 0 to $10 \mathrm{~g} \cdot \mathrm{L}^{-1}$ with the removal efficiencies about $95 \%$ and $98 \%$, respectively. When the salinity increased to $15 \mathrm{~g} \cdot \mathrm{L}^{-1}$ and $20 \mathrm{~g} \cdot \mathrm{L}^{-1}$, a decrease of TOC removal was detected, which dropped to around $91 \%$. In contrast to the decrease of TOC removal, the $\mathrm{NH}_{4}{ }^{+}-\mathrm{N}$ removal efficiency was as high as $97 \%$ at $15 \mathrm{~g} \cdot \mathrm{L}^{-1}$ salinity and then followed by notable decreases. By increasing the salinity to $35 \mathrm{~g} \cdot \mathrm{L}^{-1}$, an even more prominent reduction of the TOC and $\mathrm{NH}_{4}{ }^{+}-\mathrm{N}$ removal efficiencies was encountered. The TOC and $\mathrm{NH}_{4}{ }^{+}-\mathrm{N}$ removal efficiencies dropped to about $83 \%$ and $70 \%$, respectively.

It is obvious that there is no significant influence of salinity under $10 \mathrm{~g} \cdot \mathrm{L}^{-1}$ on system performance. The system still showed a good removal at 15 and $20 \mathrm{~g} \cdot \mathrm{L}^{-1}$ while slightly decrease was occurred. And then, a poor effluent quality was observed at $35 \mathrm{~g} \cdot \mathrm{L}^{-1}$. This finding seems to indicate 
TABLE 3: Variations and removal efficiencies of $\mathrm{NH}_{4}{ }^{+}-\mathrm{N}$ in five IAMBRs of different salinity during steady operations.

\begin{tabular}{lccc}
\hline Salinity $\left(\mathrm{g} \cdot \mathrm{L}^{-1}\right)$ & Influent $\left(\mathrm{mg} \cdot \mathrm{L}^{-1}\right)$ & Effluent $\left(\mathrm{mg} \cdot \mathrm{L}^{-1}\right)$ & Removal efficiency $(100 \%)$ \\
\hline 0 & $32.05 \pm 11.45$ & $0.45 \pm 1.03$ & $98.58 \pm 2.51$ \\
5 & $32.88 \pm 7.06$ & $0.59 \pm 0.60$ & $98.19 \pm 2.08$ \\
10 & $32.39 \pm 9.48$ & $0.47 \pm 0.61$ & $98.50 \pm 2.12$ \\
15 & $30.91 \pm 4.54$ & $0.77 \pm 0.27$ & $97.47 \pm 0.91$ \\
20 & $32.11 \pm 4.74$ & $2.07 \pm 1.11$ & $93.48 \pm 3.56$ \\
35 & $31.17 \pm 6.49$ & $9.31 \pm 2.39$ & $70.12 \pm 2.79$ \\
\hline
\end{tabular}

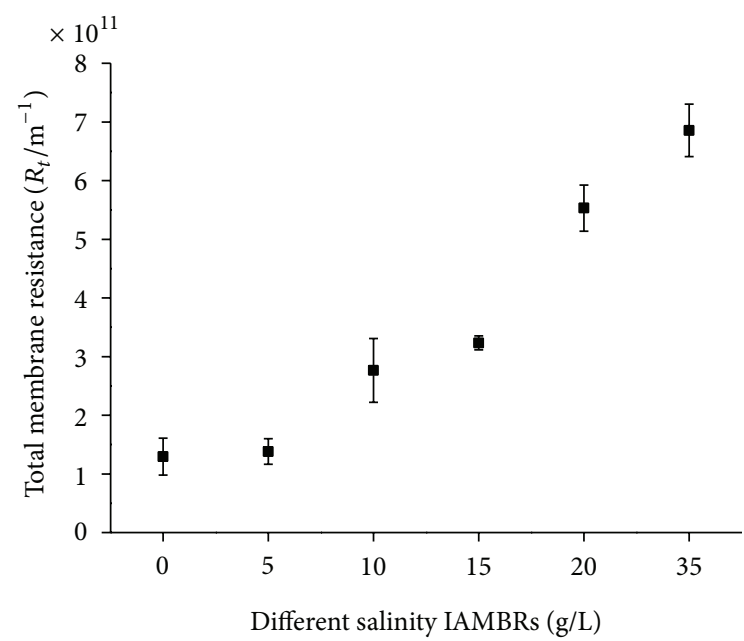

FIGURE 2: The variation of total membrane resistance at different salinity.

that elevated salinity environment leads to slow the activity of microorganisms in systems and consequently shows a lower removal. The majority of microorganisms in systems regarding as the conventional activated sludge always are the nonhalophilic [19]. They are normally able to tolerate lower salinity up to $10 \mathrm{~g} \cdot \mathrm{L}^{-1}$ without acclimation. Furthermore, the acclimation of microorganisms can work for salinity up to about $30 \mathrm{~g} \cdot \mathrm{L}^{-1}$. Nonetheless, when the salinity increased to $35 \mathrm{~g} \cdot \mathrm{L}^{-1}$, the higher osmotic stress would cause an outward flow of intracellular water, leading to cell dehydration and eventually plasmolysis and loss of activity of the cells for these microorganisms [20].

3.2. Evaluation of Filtration Resistance. In order to determine the membrane fouling, the filtration resistances at different salinity were analyzed (Figure 2). As is shown in Figure 2, the total membrane resistance increased gradually from 1.29 $\times 10^{11} \mathrm{~m}^{-1}$ to $6.85 \times 10^{11} \mathrm{~m}^{-1}$ with the salinity increased from $0 \mathrm{~g} \cdot \mathrm{L}^{-1}$ to $35 \mathrm{~g} \cdot \mathrm{L}^{-1}$. It also can be seen that there was little increasing from $0 \mathrm{~g} \cdot \mathrm{L}^{-1}$ to $5 \mathrm{~g} \cdot \mathrm{L}^{-1}$ salinity, indicating a favorable toleration of membrane fouling under $5 \mathrm{~g} \cdot \mathrm{L}^{-1}$ salinity. However, when the salinity continuously increased to $35 \mathrm{~g} \cdot \mathrm{L}^{-1}$, the total membrane resistance showed a notable increasing, aggravating membrane fouling.

This implies that salinity exerts a positive impact on the membrane fouling. The membrane fouling is a complex

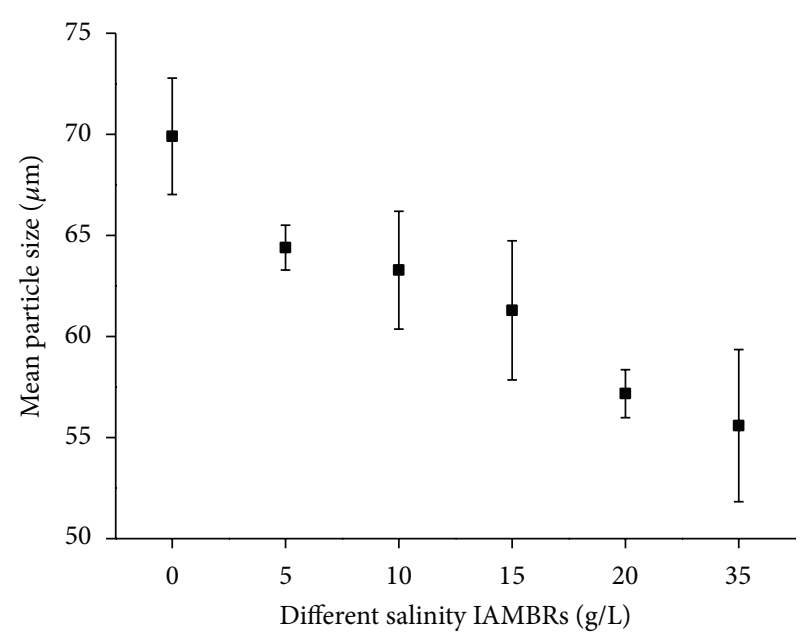

FIGURE 3: The variation of PSD at different salinity.

phenomenon in an elevated salt environment, which might be caused by inorganic fouling (main phenomenon is slat scaling), organic fouling (main phenomenon is colloidal fouling), biofouling, and their interactions. The higher salt environment can cause scaling on membrane [21] and can also aggravate colloidal fouling [22]. The deposition, growth, and metabolism of bacteria cells or flocs always result in biofouling. These findings can be reflected by sludge characteristics, such as PSD, EPS, SMP, and RH. Therefore, the sludge characteristics were further analyzed in this study to expand our knowledge of relations between sludge characteristics and membrane fouling.

3.3. Changes of PSD of Activated Sludge at Different Salinity. Variation of PSD of mixed liquors at different salinity IAMBRs is depicted in Figure 3. The mean particle size was evaluated on the basis of number of particles. It is evident that particle size decreased obviously along with increasing salinity. The particle size dropped from $69.9 \mu \mathrm{m}$ to $55.95 \mu \mathrm{m}$, while the salinity increased from 0 to $35 \mathrm{~g} \cdot \mathrm{L}^{-1}$.

In contrast to the continuous increase of total membrane resistance, the smaller particle size tended to result in higher membrane fouling. This could be explained by the The Carman-Kozeny equation (3) [23].

$$
\alpha=\frac{180 \times(1-\varepsilon)}{\rho_{p} d_{p}^{2} \varepsilon^{3}},
$$




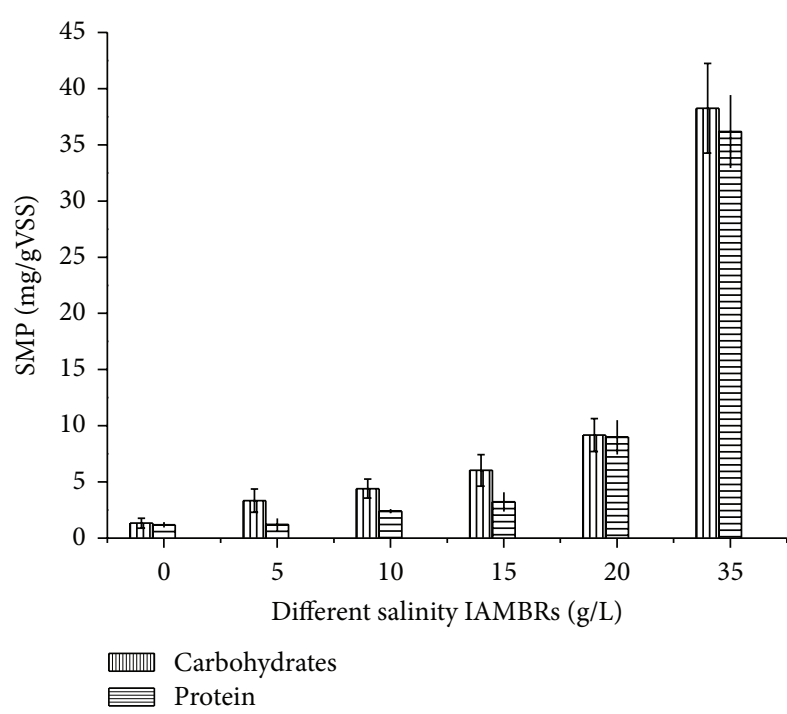

(a)

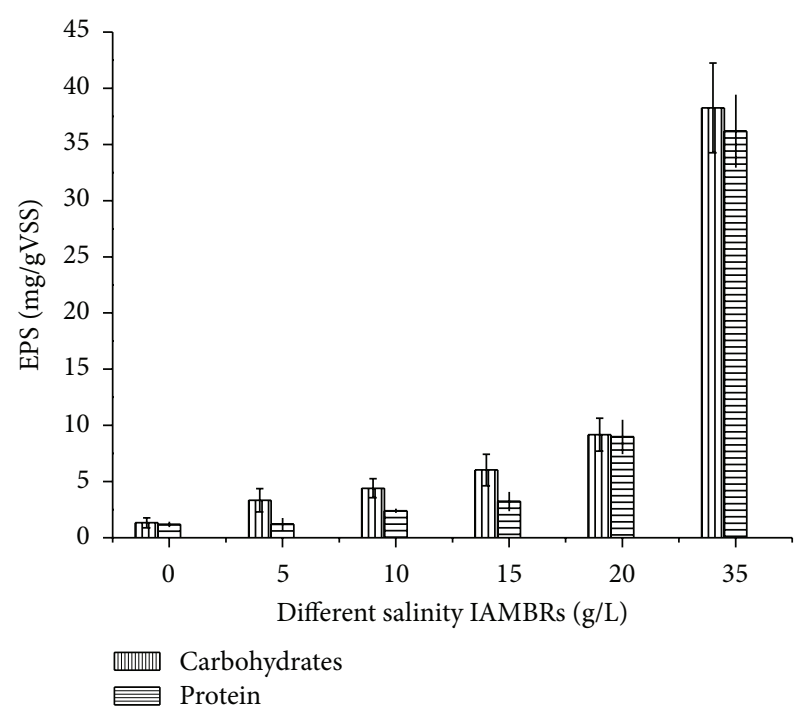

(b)

FIGURE 4: The variation of SMP (a) and EPS (b) at different salinity. The error bars show the standard deviation of the total concentrations in both (a) and (b).

where $\alpha$ is the specific cake resistance $(\mathrm{m} / \mathrm{Kg}), \varepsilon$ is the cake porosity, $d_{p}$ is the particle size $(\mathrm{m})$, and $\rho_{p}$ is the particle density $\left(\mathrm{Kg} / \mathrm{m}^{3}\right)$.

As can be clearly seen from (3), the specific resistance of the cake layer is closely related to particle size. That is to say, the smaller particles deposit on the membrane surface/in the cake layer will cause greater specific resistance. The finding in this study corroborated that a significant decrease in particle size could intensify membrane fouling within the IAMBRs system at increased salinity. The larger particles can enlarge the void fraction of the cake [23] and then reduced the specific cake resistance according to (3). Meanwhile, larger particles cannot easily deposit onto the membrane surface at a high cross flow velocity because of the high shear force. On the contrary, the smaller particles can reduce the void fraction and can be back transported less efficiently from the membrane surface [23].

3.4. Effect of Salinity on EPS and SMP. Regarding the organic foulants, the SMP and EPS are considered as the most significant factor responsible for membrane fouling [24]. Both SMP and EPS are very heterogeneous and always consist of carbohydrates, proteins, lipids, and nucleic acids. In this study, the SMP and EPS normalized as the sum of total carbohydrates and proteins because these are the dominant components typically found in extracted SMP and EPS. Figures 4(a) and 4(b) compare the SMP and EPS concentrations at different salinity and show the average concentration of SMP and EPS in each IAMBR based on duplicate measurements.

As can be seen from Figure 4, the average concentrations of SMP and EPS increased gradually with the salinity increased from 0 to $20 \mathrm{~g} \cdot \mathrm{L}^{-1}$ and then followed by significant increase at $35 \mathrm{~g} \cdot \mathrm{L}^{-1}$ salinity. For SMP, carbohydrates and proteins increased, when the salinity increased from 0 to $35 \mathrm{~g} \cdot \mathrm{L}^{-1}$ and from 1.32 and $1.19 \mathrm{mg} / \mathrm{gVSS}$ to 38.25 and $36.19 \mathrm{mg} / \mathrm{gVSS}$, respectively. So is EPS. The carbohydrates and proteins increased from 24.36 and $59.59 \mathrm{mg} / \mathrm{gVSS}$ to 270.19 and $324.5 \mathrm{mg} / \mathrm{gVSS}$, respectively.

As compared to filtration resistance in Figure 2, it appears that increasing SMP and EPS is more closely related to membrane fouling. It is generally indicated that the SMP and EPS are the dominating fouling agents resulting in membrane pore blocking. Currently, more attention is paid to SMP in mixed liquors which often affect the structure and porosity of cake layer created on the membrane surface. Figure 4(a) points that the concentrations of carbohydrates in SMP are higher than these of proteins for all of 5 different salinity IAMBRs. This implies carbohydrates were identified as a majority component of SMP. The previous studies also confirmed that the concentration of carbohydrates in the mixed liquor played an important role in membrane fouling. Figure 4(b) shows the similar increasing tendency as EPS. However, the proteins exerted an adverse impact on the membrane fouling, which is higher than carbohydrates. It seems to assume that the excreted protein in mixed liquors increased with decrease in microbial activity as salinity elevated and the carbohydrate regarding as available carbon declined.

Additionally, it has to be mentioned that the SMP and EPS concentrations were significantly increased at $35 \mathrm{~g} \cdot \mathrm{L}^{-1}$ salinity due to the more biopolymers excreted by sludge mixture. This could be in response to salt shock. Microorganisms generally accelerate endogenous respiration $[25,26]$ and secrete organic cellular constituents [27] at higher salinity, meaning loss of activity. Furthermore, the poor removal 
efficiencies of TOC and $\mathrm{NH}_{4}{ }^{+}-\mathrm{N}$ at $35 \mathrm{~g} \cdot \mathrm{L}^{-1}$ salinity were thus mainly attributable to the lower activity of microorganisms.

3.5. Variation of $R H$ at Different Salinity. The RH is considered as one of the main factors to reflect the characteristics of sludge mixture, which is measured as adherence to hydrocarbons. It is assumed that hydrophobic interactions and polymeric entanglement could enhance the sludge floc fractions cohesion, tending to clog membrane.

The results of variation of $\mathrm{RH}$ at different salinity are presented in Figure 5. It is obvious that the RH increased from $63 \%$ to $88 \%$ with the salinity increased from 0 to $20 \mathrm{~g} \cdot \mathrm{L}^{-1}$. The result is in accordance with filtration resistance. The higher RH could lead to intensify membrane fouling. These observations are probably attributed to sludge characteristics deteriorated following increased salinity [12], resulting in an increase of the hydraulic resistance.

However, when the salinity increased to $35 \mathrm{~g} \cdot \mathrm{L}^{-1}$, the $\mathrm{RH}$ dropped to $72 \%$, quickly. This finding is incompatible with that mentioned above. The most important effect of salinity on membrane fouling in numerous research is not well established. Particularly, the membrane fouling is probably attributed to the interactions of sludge characteristics caused by salinity. Only one factor cannot reflect the reason of higher membrane fouling. The decrease of $\mathrm{RH}$ at higher salinity in this study is postulated to the loss of sludge activity. Figure 6 shows the change of sludge activity. The DHA was used to characterize sludge activity. It can be seen from Figure 6 that the DHA dropped quickly when the salinity increased to $35 \mathrm{~g} \cdot \mathrm{L}^{-1}$, regarding as the loss of sludge activity. This result probably leads to the poor performance of the TOC and $\mathrm{NH}_{4}{ }^{+}-\mathrm{N}$ removal and the loss of sludge activity.

\section{Conclusions}

This study compared the performance and the sludge characteristics in IAMBRs treating the different synthetic wastewater from 0 to $35 \mathrm{~g} \cdot \mathrm{L}^{-1}$ salinity levels. The results of the removal of TOC and $\mathrm{NH}_{4}{ }^{+}-\mathrm{N}$ showed a poor performance at higher salinity. The sludge characteristics analysis showed that filtration resistance, SMP, and EPS gradually increased following the salinity increased from 0 to $35 \mathrm{~g} \cdot \mathrm{L}^{-1}$. Differently, the mean particle size of sludge mixture decreased with the elevated salinity. The RH increased with the salinity increased from 0 to $20 \mathrm{~g} \cdot \mathrm{L}^{-1}$, while dropping quickly at $35 \mathrm{~g} \cdot \mathrm{L}^{-1}$ salinity, indicating the loss of microbial activity. The membrane fouling may be attributed to the interactions of the variation of sludge characteristics caused by salinity. Therefore, the further study should be paid more attention to expand our knowledge of the relation between the membrane fouling and sludge characteristics in salinity wastewater.

\section{Conflict of Interests}

The authors declare that there is no conflict of interests regarding the publication of this paper.

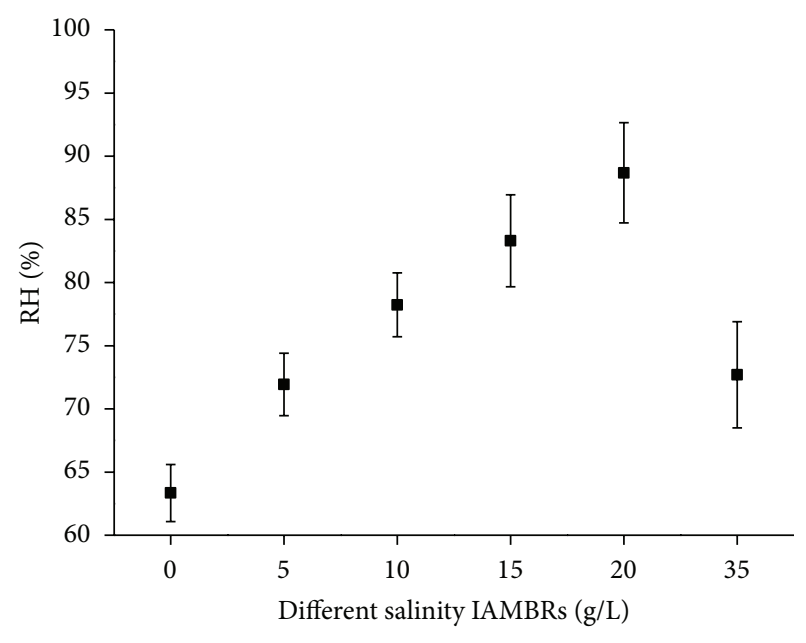

FIGURE 5: The variation of RH at different salinity.

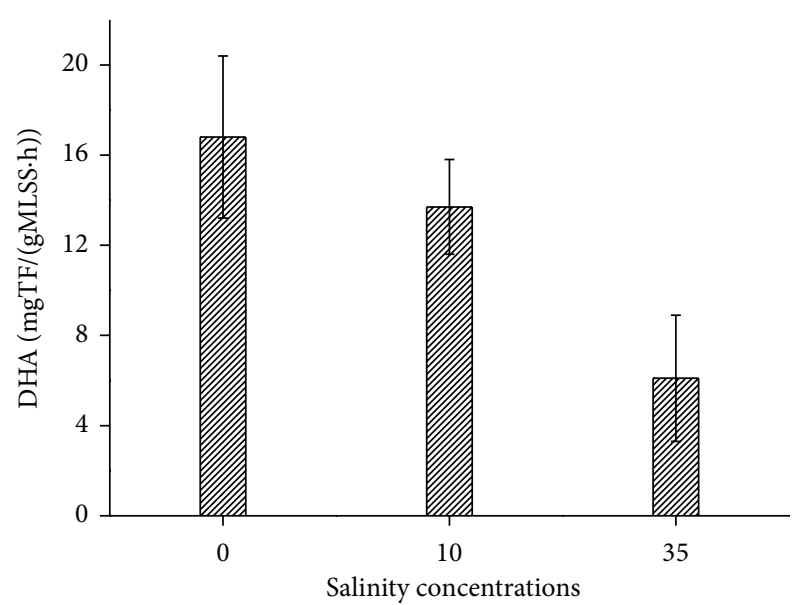

FIGURE 6: The variation of DHA at different salinity.

\section{Acknowledgments}

The authors thank the Research Fund for the Doctoral Program of University of Jinan (no. XBS1339) and the National Natural Science Foundation of China (no. 51278225) for the financial support.

\section{References}

[1] C. Kappel, A. J. B. Kemperman, H. Temmink, A. Zwijnenburg, H. H. M. Rijnaarts, and K. Nijmeijer, "Impacts of NF concentrate recirculation on membrane performance in an integrated MBR and NF membrane process for wastewater treatment," Journal of Membrane Science, vol. 453, pp. 359-368, 2014.

[2] S. Xia, J. Li, S. He et al., "The effect of organic loading on bacterial community composition of membrane biofilms in a submerged polyvinyl chloride membrane bioreactor," Bioresource Technology, vol. 101, no. 17, pp. 6601-6609, 2010.

[3] F. Meng, S. Chae, A. Drews, M. Kraume, H. Shin, and F. Yang, "Recent advances in membrane bioreactors (MBRs): membrane fouling and membrane material," Water Research, vol. 43, no. 6, pp. 1489-1512, 2009. 
[4] H. S. You, C. C. Tseng, M. J. Peng, S. H. Chang, Y. C. Chen, and S. H. Peng, "A novel application of an anaerobic membrane process in wastewater treatment," Water Science and Technology, vol. 51, no. 6-7, pp. 45-50, 2005.

[5] U. Sudarno, J. Winter, and C. Gallert, "Effect of varying salinity, temperature, ammonia and nitrous acid concentrations on nitrification of saline wastewater in fixed-bed reactors," Bioresource Technology, vol. 102, no. 10, pp. 5665-5673, 2011.

[6] O. Lefebvre and R. Moletta, "Treatment of organic pollution in industrial saline wastewater: a literature review," Water Research, vol. 40, no. 20, pp. 3671-3682, 2006.

[7] O. Lefebvre, S. Quentin, M. Torrijos, J. J. Godon, J. P. Delgenès, and R. Moletta, "Impact of increasing $\mathrm{NaCl}$ concentrations on the performance and community composition of two anaerobic reactors," Applied Microbiology and Biotechnology, vol. 75, no. 1, pp. 61-69, 2007.

[8] L. S. Tam, T. W. Tang, W. Y. Leung, G. H. Chen, and K. R. Sharma, "A pilot study on performance of a membrane bioreactor in treating fresh water sewage and saline sewage in Hong Kong," Separation Science and Technology, vol. 41, no. 7, pp. 1253-1264, 2006

[9] J. Zhang, Y. Zhang, and X. Quan, "Electricity assisted anaerobic treatment of salinity wastewater and its effects on microbial communities," Water Research, vol. 46, no. 11, pp. 3535-3543, 2012.

[10] D. Jang, Y. Hwang, H. Shin, and W. Lee, "Effects of salinity on the characteristics of biomass and membrane fouling in membrane bioreactors," Bioresource Technology, vol. 141, pp. 5056, 2013.

[11] M. A. H. Johir, S. Vigneswaran, J. Kandasamy, R. BenAim, and A. Grasmick, "Effect of salt concentration on membrane bioreactor (MBR) performances: detailed organic characterization," Desalination, vol. 322, pp. 13-20, 2013.

[12] G. Di Bella, D. Di Trapani, M. Torregrossa, and G. Viviani, "Performance of a MBR pilot plant treating high strength wastewater subject to salinity increase: analysis of biomass activity and fouling behaviour," Bioresource Technology, vol. 147, pp. 614-618, 2013.

[13] Y. Tian and X. Su, "Relation between the stability of activated sludge flocs and membrane fouling in MBR: under different SRTs," Bioresource Technology, vol. 118, pp. 477-482, 2012.

[14] K. Xie, S. Xia, J. Song et al., "The effect of salinity on ammoniaoxidizing bacterial community in the Conventional Sequencing Batch Reactor (CSBR) and Intermittently Aerated Membrane Bioreactor (IAMBR)," Fresenius Environmental Bulletin, vol. 21, no. 1, pp. 153-162, 2012.

[15] Chinese NEPA, Water and Wastewater Monitoring Methods, Chinese Environmental Science Publishing House, Beijing, China, 4th edition, 2002.

[16] C. Nagendranatha Reddy, A. Naresh Kumar, J. Annie Modestra, and S. Venkata Mohan, "Induction of anoxic microenvironment in multi-phase metabolic shift strategy during periodic discontinuous batch mode operation enhances treatment of azo dye wastewater," Bioresource Technology, vol. 165, pp. 241-249, 2014.

[17] F. Meng, F. Yang, B. Shi, and H. Zhang, "A comprehensive study on membrane fouling in submerged membrane bioreactors operated under different aeration intensities," Separation and Purification Technology, vol. 59, no. 1, pp. 91-100, 2008.

[18] B. Wilén, B. Jin, and P. Lant, "The influence of key chemical constituents in activated sludge on surface and flocculating properties," Water Research, vol. 37, no. 9, pp. 2127-2139, 2003.
[19] C. R. Woolard and R. L. Irvine, "Treatment of hypersaline wastewater in the sequencing batch reactor," Water Research, vol. 29, no. 4, pp. 1159-1168, 1995.

[20] A. Uygur, "Specific nutrient removal rates in saline wastewater treatment using sequencing batch reactor," Process Biochemistry, vol. 41, no. 1, pp. 61-66, 2006.

[21] W. C. L. Lay, Y. Liu, and A. G. Fane, "Impacts of salinity on the performance of high retention membrane bioreactors for water reclamation: a review," Water Research, vol. 44, no. 1, pp. 21-40, 2010.

[22] J. H. Choi, S. H. Lee, K. Fukushi, and K. Y. Yamamoto, "Comparison of sludge characteristics and PCR-DGGE based microbial diversity of nanofiltration and microfiltration membrane bioreactors," Chemosphere, vol. 67, no. 8, pp. 1543-1550, 2007.

[23] C. Ma, S. Yu, W. Shi, S. G. J. Heijman, and L. C. Rietveld, "Effect of different temperatures on performance and membrane fouling in high concentration PAC-MBR system treating micropolluted surface water," Bioresource Technology, vol. 141, pp. 1924, 2013.

[24] F. Meng, F. Yang, J. Xiao, H. Zhang, and Z. Gong, "A new insight into membrane fouling mechanism during membrane filtration of bulking and normal sludge suspension," Journal of Membrane Science, vol. 285, no. 1-2, pp. 159-165, 2006.

[25] D. F. Kincannon and A. F. Gaudy, "Response of biological waste treatment systems to changes in salt concentrations," Biotechnology and Bioengineering, vol. 10, pp. 483-496, 1968.

[26] M. Ingram, "The influence of sodium chloride and temperature on the endogenous respiration of Bacillus cereus," Journal of General Physiology, vol. 23, pp. 773-778, 1940.

[27] E. Reid, X. Liu, and S. J. Judd, "Effect of high salinity on activated sludge characteristics and membrane permeability in an immersed membrane bioreactor," Journal of Membrane Science, vol. 283, no. 1-2, pp. 164-171, 2006. 

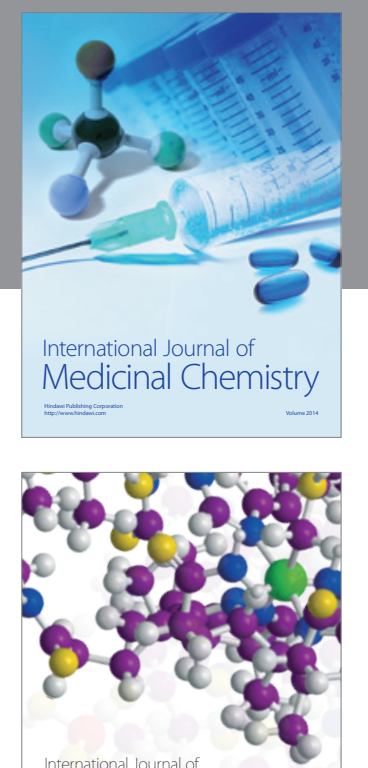

\section{Carbohydrate} Chemistry

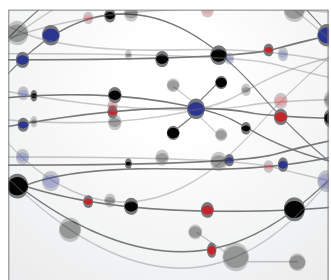

The Scientific World Journal
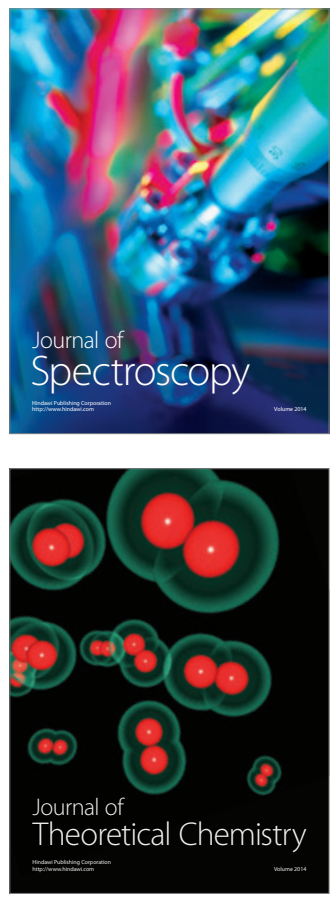
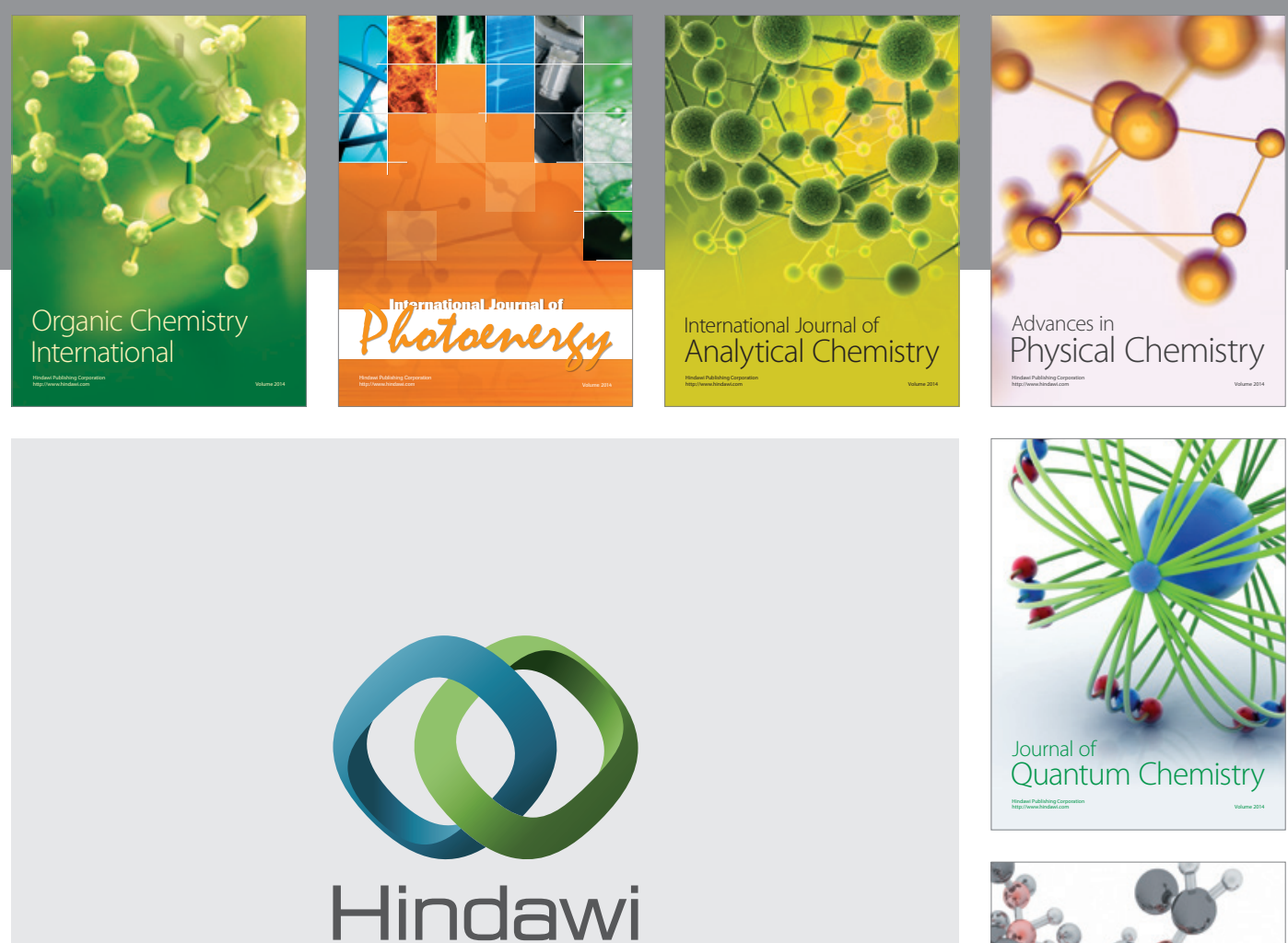

Submit your manuscripts at

http://www.hindawi.com

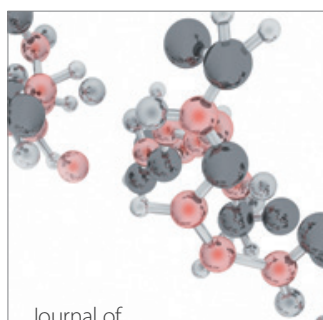

Analytical Methods

in Chemistry

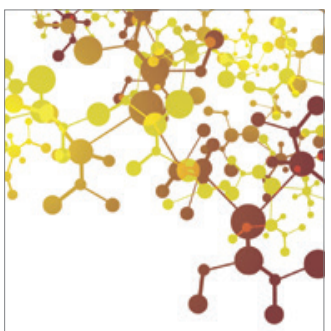

Journal of

Applied Chemistry

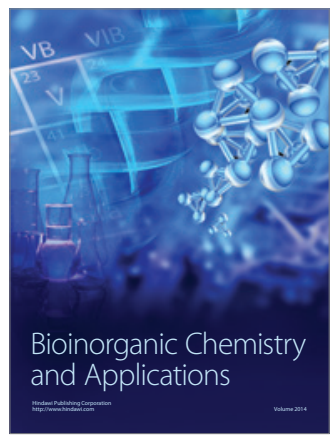

Inorganic Chemistry
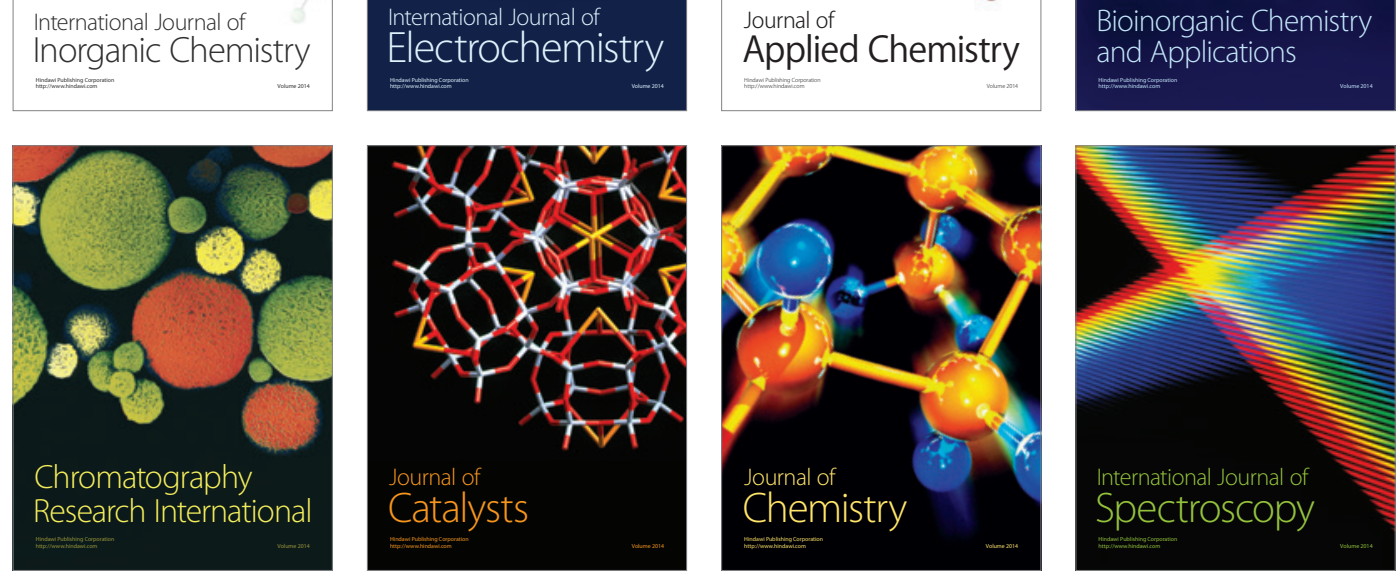